\title{
Jurnal Ilmiah METADATA \\ PENANGGULANGAN PENYIMPANGAN SEKSUAL LGBT DALAM PERSPEKTIF KEBIJAKAN KRIMINAL (CRIMINAL POLICY)
}

\author{
Tengku Mabar Ali, Suhaidi, Mustamam \\ Mahasiwa Program Magister Ilmu Hukum (S2) \\ Pascasarjana Fakultas Hukum Universitas Islam Sumatera Utara \\ Email : tengku_mabarali@yahoo.mail.com,
}

\begin{abstract}
ABSTRAK
Pengaturan hukum atau kebijakan hukum pidana terhadap penyimpangan seksual yang dilakukan lesbian, guy, biseksual dan transgender terus menjadi perdebatan di tengah masyarakat, khususnya di kalangan aktivis pegiat HAM dan para komunitas gerakan lesbian, guy, biseksual dan transgender. Penelitian ini merupakan penelitian yuridis normatif yang didukung dengan penelitian empiris, mengenai penanggulangan LGBT dalam perspektif kebijakan kriminal. Penelitian ini bersifat deskriptif analisis, dengan menggunakan sumber data primer dan sekunder. Analisis data yang digunakan dalam penelitian ini yaitu analisis data kualitatif. Pengaturan lesbian, guy, biseksual dan transgender dalam perundangundangan di Indonesia, belum diatur dalam KUHP. Ketentuan hukum yang mengatur LGBT dalam KUHP hanya diatur dalam Pasal 292 KUHP, yang hanya diperuntukkan terhadap perbuatan cabul sesama jenis yang dilakukan terhadap anak di bawah umur. Sementara perbuatan cabul sesama jenis antara orang dewasa belum diatur dalam KUHP maupun RKUHP. Perumusan perbuatan LGBT dalam perpsektif kebijakan kriminal adalah hal yang urgen, mengingat perbuatan LGBT bertentangan dengan hukum yang berlaku di Indonesia dan bertentangan dengan nilai-nilai Pancasila. Kebijakan formulasi perbuatan LGBT dalam perspektif kebijakan kriminal, dilakukan atas berbagai pendekatan, salah satunya adalah pendekatan nilai-nilai dan norma-norma yang berlaku di masyarakat. Dalam merumuskan perbuatan LGBT, dapat diformulasikan dalam RKUHP yang baru, yaitu dalam melakukan perluasan terhadap Pasal 284 dan Pasal 292 KUHP.
\end{abstract}

Kata Kunci : Penanggulangan, LGBT, Kebijakan Kriminal

\section{PENDAHULUAN}

Polemik LGBT di Indonesia telah menimbulkan pro dan kontra di masyarakat. Sebagian kelompok masyarakat berpendapat bahwa LGBT adalah sebuah "fakta", sehingga harus diberi hak setara di dalam undang-undang sebagaimana telah dilakukan di berbagi negara. Di pihak lain, kelompok yang kontra berpendapat hubungan sesama jenis telah bertentangan moral, agama budaya, karena menyalahi aturan yang sudah ditentukan sebagai kodrat manusia. LGBT tidak saja merubah 
kodrat manusia, tetapi juga berimbas pada timbulnya kejahatan baru atau kriminalitas, jika kejahatan itu dibiarkan, maka akan berakibat buruk pada masa depan bangsa Indonesia, yaitu terjadinya degradasi moral bangsa, bahkan dapat merusak peradaban manusia Indonesia di masa depan”. (Mulyono, 2012).

LGBT saat ini masih dipandang sebagai bentuk penyimpangan sosial, yaitu penyimpangan orientasi seksual yang dilakukan oleh sekelompok orang. Para pelaku $L G B T$ memiliki orientasi seksual yang menyimpang (abnormal), yang oleh sebagian orang dianggap sebagai penyakit. Namun, realitanya $L G B T$ terus berkembang di masyarakat, khususnya di kota-kota besar di Indonesia. Bahkan kelompok $L G B T$ berupaya agar pemerintah dapat mengakui eksistensi mereka secara sosial dan hukum dengan melegalkan pernikahan sejenis.

Perilaku LGBT dianggap sebagai bentuk ekspresi dari orientasi seksual terhadap sesama jenis. Konsep mencintai tidak semata diletakkan pada konteks perbedaan jenis kelamin melainkan lebih diutamakan pada relasi cinta dan kasih sayang diantara individu-individu tanpa melihat pada jenis kelamin. Orientasi seksual ini menurut beberapa pihak dianggap sebagai perilaku alami dan bukanlah bentuk dari sebuah perilaku jahat.

Perilaku menyimpang $L G B T$ tentunya telah menimbulkan keresahan di tengah masyarakat, bahkan keberadaan $L G B T$ menimbulkan kerugian bagi masyarakat. Bagaimana tidak, kelompok $L G B T$ saat ini terus berjuang untuk mendapatkan pengakuan atas eksistensi mereka sebagaimana terjadi di beberapa negara maju, seperti Amerika Serikat yang melegalkan perkawinan sesama jenis, yang jelas-jelas bertentangan dengan nilai-nilai dan norma-norma yang hidup di tengah masyarakat Indonesia.

Persepsi masyarakat dalam menyikapi keberadaan $L G B T$ di Indonesia memang cukup beragam. Secara umum, persepsi masyarakat terhadap lesbian, guy, biseksual dan transgender dapat dikelompokkan ke dalam 4 (empat) kelompok, yang menjadi titik penting dalam perdebatan lesbian, guy, biseksual dan transgender di Indonesia, yaitu: perspektif agama (religius), perspektif Hak Asasi 


\section{Jurnal Ilmiah METADATA}

Manusia (HAM), perspektif psikologi dan persfektip hukum, khususnya hukum pidana. (Rustam, 2016).

Terlepas dari pro kontra yang terjadi, harus diakui bahwa $L G B T$ merupakan suatu fenomena atau gejala sosial, karena telah bertentangan dengan norma-norma dan nilai-nilai, baik itu agama, budaya maupun nilai-nilai Pancasila sebagai dasar falsafah hidup bangsa. Dengan demikian, LGBT sebernarnya telah melanggar hak orang lain, karena hampir sebagian besar masyarakat Indonesia menolak keberadaan $L G B T$.

Perspektif negara hukum Pancasila yang dianut negara Indonesia, perilaku LGBT tidak saja dipandang sebagai bentuk penyimpangan orientasi seksual yang merupakan problema pribadi (privacy), sehingga negara tidak perlu terlalu mencampuri urusan tersebut. Namun, LGBT dapat dipandang sebagai fenomena sosial atau penyimpangan sosial, karena telah bertentangan dengan norma-norma yang berlaku di masyarakat. Dalam hal suatu perbuatan telah bertentangan dengan norma-norma dan nilai-nilai yang hidup dalam masyarakat, maka perbuatan tersebut dapat pula dipandang sebagai suatu bentuk kejahatan.

Tafsir mengenai kejahatan seringkali dihubungkan dengan perbuatan melawan hukum (melawan norma hukum pidana), yang berarti bahwa suatu perbuatan baru dapat dipandang sebagai suatu kejahatan atau tindak pidana, jika telah dirumuskan dalam undang-undang. Dalam konsep hukum pidana, pandangan demikian dikenal sebagai bentuk perwujudan asas legalitas. Asas legalitas dalam konsep hukum pidana Indonesia merupakan fondasi atau pilar dasar dalam berlakunya hukum pidana. Asas ini secara ekplisit disebutkan dalam rumusan Pasal 1 KUHP, yang menyebutkan: "Tiada satu perbuatan boleh dihukum, melainkan atas kekuatan ketentuan pidana dalam undang-undang, yang ada terdahulu dari pada perbuatan itu". (Soesilo, 2010).

LGBT merupakan bagian yang inheren dalam konteks kehidupan bangsa Indonesia. Pengakuan terhadap eksistensi kaum LGBT akan berdampak pada pembentukan peradaban yang baru, mengingat darinya tidak akan dapat dilahirkan generasi manusia baru. Terlebih tuntutan atas legitimasi perkawinan sejenis yang 
terus diusahakan, pengakuan Negara terhadap perkawinan sesama jenis tentunya akan berimplikasi pada hilangnya makna sebuah keluarga sebagai pembentuk terciptanya peradaban masyarakat yang bermoral di masa depan.

Perihal belum dirumuskan dan diaturnya suatu perbuatan dalam undangundang, perspektif kebijakan kriminal dikenal dengan istilah kriminalisasi. Kriminalisasi merupakan bagian dari politik hukum pidana yang pada intinya merupakan kebijakan bagaimana merumuskan hukum pidana yang baik dan memberikan pedoman dalam pembuatan (kebijakan legislatif), aplikasi (kebijakan yudikatif), dan pelaksanaan (kebijakan eksekutif) hukum pidana. (Soekanto, 1981).

Politik hukum pidana sendiri merupakan bagian dari politik hukum yang menurut Sudarto diartikan sebagai serangkaian usaha untuk menciptakan normanorma hukum yang sesuai dengan situasi dan kondisi pada masa tertentu. Politik hukum menyangkut ius constituendum, yaitu hukum dimasa mendatang yang dicita-citakan. (Sudarto, 2007)

Berdasarkan uraian singkat latar belakang di atas, masalah perilaku seksual menyimpang $L G B T$ perlu untuk dikaji lebih mendalam, khususnya mengenai kebijakan kriminal yang akan dilakukan oleh pemerintah didalam upaya penanggulangan penyimpangan seksual $L G B T$ yang telah menimbulkan keresahan di tengah masyarakat.

\section{METODE PENELITIAN}

Penelitian ini tergolong sebagai penelitian hukum normatif. Data penelitian ini bersumber dari data sekunder yang bersumber dari bahan-bahan hukum, yang terdiri dari bahan hukum primer, sekunder dan tersier. Penelitian ini menggunakan pendekatan undang-undang dan pendekatan konseptual. Analisis data dalam penelitian ini menggunakan analisis data kualitatif.

\section{HASIL DAN PEMBAHASAN}

Secara konstitusional, kontruksi hukum hubungan seksualitas di Indonesia tertuang dalam Undang-Undang Dasar Negara Republik Indonesia, yaitu Pasal 28 
B UUD RI Tahun 1945, yang berbunyi: "setiap orang berhak membentuk keluarga dan melanjutkan keturunan melalui perkawinan yang sah”. Ketentuan konstitusi tersebut dapat dipahami bahwa setiap warga negara Indonesia memiliki hak yang sama untuk membentuk keluarga dan melanjutkan keturunan melalui perkawinan yang sah, yaitu sesuai dengan ketentuan Undang-Undang No. Tahun 1974 tentang Perkawinan.

Pasal 28 B UUD RI Tahun 1945 kemudian dijabarkan dalam Undang-Undang No. 1 Tahun 1974 Tentang Perkawinan (selanjutnya disingkat Undang-Undang Perkawinan). Dalam Pasal 1 undang-undang ini, menyebutkan bahwa: "Perkawinan ialah ikatan lahir bathin antara seorang pria dengan seorang wanita sebagai suami isteri dengan tujuan membentuk keluarga (rumah tangga) yang bahagia dan kekal berdasarkan Ketuhanan Yang Maha Esa”.

Menurut penjelasan Pasal 1 Undang-Undang Perkawinan, bahwa sebagai Negara yang berdasarkan Pancasila, di mana Sila yang pertamanya ialah Ketuhanan Yang Maha Esa, maka perkawinan mempunyai hubungan yang erat sekali dengan agama/kerohanian sehingga perkawinan bukan saja mempunyai peranan yang penting. Membentuk keluarga yang bahagia rapat hubungan dengan keturunan, yang pula merupakan tujuan perkawinan, Pemeliharaan dan Pendidikan menjadi hak dan kewajiban orang tua. Lebih lanjut, dalam Pasal 2 ayat (1) Undang-Undang Perkawinan jo Pasal 4 Kompilasi Hukum Islam, menyebutkan: "Perkawinan adalah sah apabila dilakukan menurut hukum masing-masing agamanya dan kepercayaannya itu."

Undang-Undang Perkawinan dibentuk berdasarkan pada substansi hukum yang terkandung dalam UUD RI Tahun 1945, yang menempatkan agama sebagai penentu sahnya suatu perkawinan. Di mana sahnya suatu perkawinan didasari pada ketentuan agama. Dengan demikian, prinsip perkawinan yang dianut di Indonesia adalah religious marriage, yaitu perkawinan yang didasarkan pada ajaran atau konsep agama. Jadi, sahnya perkawinan dalam hukum perkawinan nasional adalah perkawinan yang dilakukan menurut tata tertib aturan hukum yang berlaku dalam 
masing-masing agama, yaitu agama Islam, Kristen, Hindu dan Budha. (Baharuddin, 2003).

Secara garis besar kontruksi seksualitas pada perundang-undangan di Indonesia mempunyai prinsip-prinsip sebagai berikut:

a. Pertama, tujuan perkawinan adalah membentuk keluarga yang bahagia dan kekal berdasarkan Ketuhanan Yang Maha Esa.

b. Kedua, sahnya perkawinan sangat tergantung pada ketentuan hukum agama dan kepercayaan masing-masing.

c. Ketiga, pencatatan perkawinan.

d. Keempat, asas monogami.

e. Kelima, batas usia perkawinan.

f. Keenam, mempersulit terjadinya perceraian.

g. Kedelapan, hak dan kedudukan suami istri adalah seimbang.

Berdasarkan prinsip-prinsip tersebut di atas, dapat dikatakan bahwa hubungan seksual sesama jenis tidak dapat dibenarkan di Indonesia. Hal ini dikarenakan hubungan seksual sesama jenis bertentangan dengan norma-norma agama, baik itu agama Islam, Kristen, Hindu maupun Budha. Dari beberapa agama yang diakui di Indonesia, tidak ada satupun konsep ajaran agama yang membenarkan hubungan seksual sesama jenis. Hal ini berarti bahwa penyimpangan seksual yang dilakukan oleh komunitas LGBT tidak memiliki tempat dalam sistem hukum perkawinan di Indonesia, terkecuali terdapat perubahan yang signifikan terhadap Undang-Undang Perkawinan.

Penyimpangan seksual sesama jenis dalam keadaan tertentu tidak saja dipandang sebagai perbuatan menyimpang, tetapi juga merupakan suatu perbuatan pidana yang diancam dengan sanksi pidana berupa pidana penjara. Ketentuan hukum pidana yang berlaku di Indonesia, yaitu KUHP tidak mengatur mengenai penyimpangan seksual yang dilakukan oleh komunitas $L G B T$. Namun, perbuatan yang hampir mendekati perbuatan $L G B T$ diatur dalam salah satu pasal dalam KUHP, yaitu Pasal 292 KUHP, yang menyebutkan: “orang yang cukup umur, yang melakukan perbuatan cabul dengan orang lain sama kelamin, yang diketahui atau 


\section{당}

\section{Jurnal Ilmiah METADATA}

sepatutnya harus diduga, bahwa belum cukup umur, diancam dengan pidana penjara paling lama lima tahun".

Mengenai ketentuan kedewasaan dalam Pasal 292 KUHP, R. Soesilo memberikan penjelasan sebagai berikut :

Dewasa dalam Pasal 292 adalah 21 tahun atau orang yang belum 21 tahun tapi sudah menikah. Perbuatan cabul yang dimaksudkan dalam pasal ini adalah hubungan seksual antara laki-laki dengan laki atau perempuan dengan perempuan. Perbuatan itu dilakukan terhadap orang yang belum dewasa, sedangkan jika dilakukan oleh orang-orang atau semua belum dewasa atau dua orang atau semua sudah dewasa bersama-sama melakukan perbuatan ini, maka tidak dapat dihukum menurut pasal ini.

Adami Chazawi (2007), dalam bukunya yang berjudul Tindak Pidana Mengenai Kesopanan menyebut bahwa Pasal 292 KUHP sebagai perbuatan cabul sesama kelamin (homoseksual). Perbuatan cabul dalam pasal ini dilakukan oleh minimal dua orang. Namun orang yang dibebani tanggung jawab pidana adalah yang dewasa. Lebih lanjut, mengenai penjelasan Pasal 292 KUHP, Adami Chazawi (2007), memberikan penjelasan sebagai berikut:

Orang dewasa yang melakukan perbuatan cabul dengan orang yang belum dewasa dari jenis kelamin yang sama, sedang diketahuinya atau patut harus disangkanya belum dewasa, dihukum penjara selama-lamanya lima tahun. Pasal ini merupakan perlindungan bagi orang suka dengan sesama jenisnya, misal homoseksual, lesbian, pasangan sesama jenis. Berdasarkan ketentuan pasal tersebut, bukanlah solusi yang tepat untuk memberantas hubungan seksual sesama jenis. Walaupun dalam kenyataannya dilakukan oleh kedua belah pihak bersama-sama, namun yang dijatuhi hukuman hanyalah seorang yang dianggap dewasa. Akan tetapi bagi orang yang di bawah umur, perlu dilindungi dari orang dewasa yang homoseksual atau lesbian, karena sangat berbahaya bagi perkembangan masa depannya.

Berdasarkan ketentuan di atas, diketahui bahwa ketentuan hukum tentang hubungan seksual sesama jenis diatur dalam Pasal 292 KUHP. Namun, ketentuan ini hanya dapat diterapkan pada hubungan antara orang dewasa dengan orang yang belum dewasa (anak-anak). Sedangkan terhadap hubungan sesama jenis yang dilakukan oleh dua orang yang telah dewasa secara bersama-sama tidak dapat diancam dengan pasal ini. 


\section{으}

Jurnal Ilmiah METADATA

Pro kontra terhadap kriminalisasi atas suatu perbuatan sampai saat ini memang masih menjadi perdebatan di kalangan pemerhati hukum pidana, terutama jika dikaitkan dengan kriteria penggunaan hukum pidana. Sebagai negara hukum yang berdasarkan pancasila, perbuatan $L G B T$ jelas-jelas telah bertentangan dengan nilai-nilai Pancasila yang menjadi dasar falsafah hidup bangsa. Oleh karena itu, perbuatan tersebut perlu dirumuskan dan diatur dalam undang-undang sehingga menjadi suatu produk hukum yang dapat dijadikan sebagai batasan atas perilaku seksual menyimpang yang selama dilakukan dan berkembang di kalangan komunitas $L G B T$.

Perumusan suatu perbuatan menjadi suatu tindak pidana dalam disilpin ilmu hukum pidana disebut kriminalisasi. Kriminalisasi adalah suatu proses penetapan suatu perbuatan yang semula bukan tindak pidana menjadi tindak pidana dan diancam dengan sanksi pidana. (Sudarto, 2007).

Kriminalisasi merupakan proses untuk menetapkan suatu perbuatan yang semula bukan merupakan tindak pidana menjadi suatu rumusan tindak pidana dalam suatu rumusan peraturan perundang-undangan. (Prasetyo, 2014). Kriminalisasi merupakan bagian dari kebijakan hukum pidana yang bertujuan untuk menciptakan ketertiban di dalam suatu masyarakat sesuai dengan fungsi hukum sebagai media pengatur interaksi sosial. Di mana dalam pengaturan tersebut terdapat petunjuk mengenai apa yang harus dilakukan mana yang boleh dan tidak boleh dilakukan dengan harapan segala sesuatunya dapat berjalan tertib dan teratur. (Mawardi, 2018).

Perumusan suatu perbuatan menjadi tindak pidana (kriminalisasi) didasari pada sejauhmana terjadinya pencelaan masyarakat terhadap perbuatan tersebut. Dengan demikian, kriminalisasi perbuatan $L G B T$ perlu dilakukan karena perbuatan tersebut dirasa sudah bertentangan dengan nilai-nilai yang hidup, tumbuh dan berkembang di dalam suatu masyarakat, sehingga berpotensi untuk menciptakan kegaduhan di dalam masyarakat tersebut. (Prasetyo, 2013).

Dasar pertimbangan perlunya diatur perbuatan $L G B T$ dalam hukum pidana adalah bahwa perbuatan LGBT dianggap sebagai perbuatan yang buruk dengan 
sendirinya (mala in se), karena perbuatan itu terlarang atas dasar kesepakatan atau konsensus masyarakat secara luas tentang tata atau norma kelakuan bagi satu larangan. Oleh karena itu, perbuatan $L G B T$ perlu dirumuskan dalam hukum pidana sebagai upaya komprehensif menanggulangi permasalahan $L G B T$ di Indonesia.

W.A. Bonger menjelaskan bahwa kejahatan merupakan perbuatan anti sosial yang secara sadar mendapatkan reaksi dari negara berupa pemberian derita dan kemudian, sebagai reaksi-reaksi terhadap rumusan hukum (legal definition) mengenai kejahatan. (Bonger, 2015).

Kebijakan atau upaya penanggulangan kejahatan pada hakikatnya merupakan bagian integral dari upaya perlindungan masyarakat (social defence) dan upaya mencapai kesejahteraan masyarakat (social welfare). Oleh karena itu, dapat dikatakan bahwa tujuan utama dari politik kriminal adalah memberi perlindungan kepada masyarakat luas didalam rangka mencapai kesejahteraan masyarakat. (Arief, 2007).

Kendati berbagai penolakan bermunculan terhadap komunitas $L G B T$ beserta segala aktifitas seksual yang dilakukannya, sampai saat ini belum terdapat pengaturan hukum yang secara konkret mengatur dan melarang aktifitas seksual yang dilakukan oleh seluruh komunitas $L G B T$ di dalam hukum positif Indonesia. Dasar rujukan LGBT sampai saat ini adalah Pasal 292 KUHP, akan tetapi Pasal 292 KUHP tidak mengakomodir perilaku seksual sejenis yang dilakukan oleh mereka yang sudah dewasa.

Belum diaturnya perbuatan cabul dan/atau hubungan seks dengan sejenis yang dilakukan oleh orang yang telah cukup umur menyebabkan perbuatan seks menyimpang oleh komunitas $L G B T$ terus mengalami perkembangan. Di sisi lain berbagai upaya terus digencarkan oleh komunitas LGBT dan bahkan dengan dukungan organisasi-organisasi lain yang berada di dalam maupun di luar negeri untuk mengkampanyekan dan melegalkan keberadaan $L G B T$ di Indonesia.

Berdasarkan pertimbangan di atas, maka pembaharuan hukum pidana Indonesia dimasa mendatang dipandang perlu (urgen) untuk merumuskan perbuatan LGBT (kriminalisasi) dalam hukum pidana dengan perluasan pengaturan 
tindak pidana hubungan seksual sesama jenis yang dilakukan oleh komunitas $L G B T$ dalam konsep RKUHP yang saat ini sedang dibahas oleh DPR, agar pasal yang mengatur mengenai hubungan seksual sesama jenis yang dilakukan oleh $L G B T$ tidak lagi terbatas hanya mengatur perbuatan cabul atau hubungan seksual sesama jenis yang dilakukan oleh seseorang yang sudah dewasa terhadap seseorang yang belum cukup umur saja. Akan tetapi, terhadap seseorang yang sudah dewasa yang melakukan hubungan seksual sesama jenis dengan orang yang juga sudah dewasa dan/atau seorang anak yang belum cukup umur melakukan hubungan seksual sesama jenis dengan sesama anak yang belum cukup umur juga harus segera diatur ke dalam suatu rumusan pasal dalam RKUHP.

Pembentukan peraturan perundang-undangan termasuk dalam konteks Peraturan perundang-undangan yang memuat ketentuan pidana, bisa dimaknai sebagai pembentukan norma baru maupun perbaikan norma yang telah ada. Diperlukannya suatu aturan atau norma baru apabila terjadi kekosongan norma. Seperti yang telah dikemukakan di awal pada bagian latar belakang, permasalah hukum dalam penelitian ini adalah adanya kekosongan norma mengenai pengaturan hukum perilaku seksual menyimpang $L G B T$.

Belum adanya norma hukum pidana yang mengatur secara tegas ancaman pidana bagi perbuatan cabul yang dilakukan oleh pasangan sesama jenis yang subjek hukumnya sama-sama dewasa. Sementara kenyataan hukum, perbuatan yang demikian ada di masyarakat dan perbutaan itu sangat mengganggu keseimbangan hukum.

Perilaku seks menyimpang $L G B T$ tentu bisa dinilai sebagai suatu perbuatan yang tidak sejalan dengan jiwa bangsa. Karena perbuatan ini membuat nilai yang terkandung dalam Pancasila terkesampingkan. Utamanya nilai dalam sila pertama sebagaimana telah dijelaskan sebelumnya. Perbuatan demikian akan mengaburkan nilai yang menjadi semangat pembangunan hukum nasional.

Selain itu, kriminalisasi terhadap perilaku seks menyimpang $L G B T$ dapat pula dilihat dari reaksi masyarakat yang ada saat sekarang ini. Di mana reaksi sebagian 
besar masyarakat saat ini menunjukan penolakan atau ketidaksepakatan untuk menerima keberadaan komunitas $L G B T$ dan perilakunya.

Pembuatan norma atau formulasi norma baru dalam hukum pidana yang mengatur mengenai larangan perilaku seksual menyimpang LGBT dapat dipahami sebagai upaya rasional yang bisa dilakukan guna menghindarkan konflik di masyarakat yang bisa berujung pada kekerasan. Selain itu, jiwa bangsa dalam konteks ke-Indonesiaan dapat dicermati dari hukum adat. Hukum adat yang didasari oleh semangat adat atau kebiasaan masyarakat yang kemudian dilengkapi dengan sanksi. Eksistensi masyarakat adat dan hukum adat di Indonesia, oleh Soepomo dijelaskan sebagai berikut:

Bangsa Indonesia dibangun dalam suatu tatanan integralistik, yang berarti sebagai masyarakat organis. Setiap diri adalah anggota dari rumpun keluarga. Pembangunan manusia Indonesia adalah pemuliaan terhadap generasi dengan jelasnya garis keturunan yang membentuk rumpun-rumpun kemasyarakatan. Hal inilah yang menjadi jati diri pertama dalam bangunan hukum nasional pasca proklamasi kemerdekaan pada 1945. (Soepomo. 1983).

Salah satu corak hukum adat di Indonesia adalah religio magis atau perilaku hukum atau kaidah-kaidah hukumnya berkaitan dengan kepercayaan terhadap yang ghaib dan untuk berdasarkan ajaran ke-Tuhanan Yang Maha Esa. Corak hukum adat yang demikian menjadi semangat masyarakat Indonesia dalam berperilaku, maka wajar jika seksual sesama jenis $L G B T$ mendapat penolakan dari masyarakat.

\section{KESIMPULAN}

1. Pengaturan lesbian, guy, biseksual dan transgender dalam perundang-undangan baik dalam KUHP maupun di luar KUHP. Ketentuan hukum yang mengatur LGBT dalam KUHP hanya diatur dalam Pasal 292 KUHP, yang hanya diperuntukkan terhadap perbuatan cabul sesama jenis yang dilakukan terhadap anak di bawah umur. Sementara perbuatan cabul sesama jenis antara orang dewasa belum diatur dalam KUHP maupun RKUHP.

2. Perumusan perbuatan $L G B T$ dalam perpsektif kebijakan kriminal adalah hal yang urgen, mengingat perbuatan $L G B T$ bertentangan dengan hukum yang 
berlaku di Indonesia dan bertentangan dengan nilai-nilai Pancasila yang didalamnya terkandung norma agama, adat dan budaya bangsa Indonesia. Selain itu, pertimbangan lainnya adalah bahwa perbuatan $L G B T$ akan merusak moralitas generasi penerusa bangsa Indonesia.

3. Kebijakan formulasi perbuatan $L G B T$ dalam perspektif kebijakan kriminal, dilakukan atas berbagai pendekatan, salah satunya adalah pendekatan nilai-nilai dan norma-norma yang berlaku di masyarakat. Dalam merumuskan perbuatan $L G B T$, dapat diformulasikan dalam RKUHP yang baru, yaitu dalam melakukan perluasan terhadap Pasal 284 dan Pasal 292 KUHP, dengan terlebih dahulu memformulasikan tentang subjek, perbuatan (delik) dan sanksi pidana yang akan diterapkan. Selain itu, perlu pula dirumuskan kebijakan non penal untuk menanggulangi perilaku seks menyimpang $L G B T$, sebagai bentuk upaya integral dalam penanggulangan kejahatan seksual $L G B T$.

\section{DAFTAR PUSTAKA}

Ahmad, Baharuddin, (2003), Hukum Perkawinan di Indonesia, Studi Historis, Jakarta: Gaung Persada Pers.

Arief, Nawawi Barda, (2010), Masalah Penegakan Hukum Indonesia, Jakarta: Prenada Kencana Media Group.

Bonger, W, (2015), Pengantar Tentang Krimonologi, Cet. Ke-VIII, Jakarta: PT. Pembangunan.

Chazawi, Adami, (2007), Tindak Pidana Mengenai Kesopanan, Jakarta: Rajawali.

Mulyono, Wahyu, (2012), Pengantar Teori Kriminologi, Yokyakarta: Pustaka Yustisia, h. 3.

Mawardi, D. R, Fungsi Hukum Dalam Kehidupan Masyarakat, Jurnal MasalahMasalah Hukum, Jilid 47 No.4, Oktober 2018, h. 44.

Rustam Dahar Karnadi Apollo Harahap, LGBT di Indonesia : Perpektif Hukum Islam, HAM, Psikologi dan Pendekatan Maslahah, Jurnal Alhakam, Volume 26, Nomor 2 Oktober 2016, h. 224.

Soesilo, R., (2016), Kitab Undang-Undang Hukum Pidana (KUHP) serta Komentar-Komentarnya Lengkap Pasal Demi Pasal, Bogor: Politea. 
Soerjono, Soekanto, (1981), Kriminologi: Suatu Pengantar, Jakarta: Ghalia Indonesia.

Sudarto, (2007), Hukum dan Hukum Pidana, Bandung: Alumni.

Siswosoebroto, Koesriani dan Peters, G. A.A, (2008), Hukum dan Perkembangan Sosial (Buku I), Jakarta: Sinar Harapan.

Prasetyo, Teguh, (2014), Hukum Pidana, Jakarta: PT RajaGrafido Persada.

, (2013), Kriminalisasi Dalam Hukum Pidana, Bandung: Penerbit Nusa Media.

Soepomo. (1983), Hubungan Individu dan Masyarakat dalam Hukum Adat, Jakarta: Pradnya Paramita. 